\title{
Organic Oxidations Using Geomimicry
}

Ziming Yang,\# Hilairy E. Hartnett,*,\#, \# School of Molecular Sciences, Arizona State University, Tempe, AZ 85287

I School of Earth and Space Exploration, Arizona State University, Tempe, AZ 85287

\section{SUPPPORTING INFORMATION}

\section{Table of Contents}

Table 1, Summary of Phenylacetic Acid Oxidation Experiment Results

Table 2, Summary of Benzyl Alcohol Oxidation Experiment Results

Table 3, Summary of Benzaldehyde Oxidation Experiment Results
Page S2

Page S3

Page S4 
Table 1. Reaction Times, initial concentrations, conversions, and chemical yields for reaction of phenyl acetic acids with $\mathrm{Cu}(\mathrm{II}) \mathrm{Cl}_{2}(0.20$ molal $)$ in $\mathrm{H}_{2} \mathrm{O}$ at $250^{\circ} \mathrm{C}$ and 40 bar in fused silica tubes.

\begin{tabular}{|c|c|c|c|c|c|c|c|c|c|}
\hline Reactant $^{a}$ & $\begin{array}{l}\text { Time } \\
\text { (hrs) }\end{array}$ & $\begin{array}{l}\text { Conv. } \\
(\%)\end{array}$ & $\begin{array}{c}\text { Initial } \\
\text { Reactant } \\
(\text { molal) } b\end{array}$ & $\begin{array}{c}\text { Initial } \\
\mathbf{C u}^{2+} \\
(\mathbf{m o l a l})\end{array}$ & $\begin{array}{c}\text { Reactant } \\
\text { Consumed } \\
(\text { molal }) \mathrm{d}\end{array}$ & $\begin{array}{c}\mathbf{C u}^{2+} \\
\text { Consumed } \\
(\text { molal }) \mathrm{e}^{\mathrm{e}}\end{array}$ & $\begin{array}{l}\text { Consumed } \\
\text { mole ratio }\end{array}$ & $\begin{array}{l}\text { Aldehyde } \\
\% \text { yield } \mathrm{g}\end{array}$ & $\begin{array}{c}\text { Mass } \\
\text { Balance } \\
(\%)\end{array}$ \\
\hline PAA & 0.17 & 68 & 0.05 & 0.20 & 0.034 & 0.13 & 3.9 & 94 & 101 \\
\hline PAA & 0.5 & 97 & 0.05 & 0.20 & 0.048 & 0.19 & 3.9 & 95 & 97 \\
\hline PAA & 2 & 98 & 0.05 & 0.20 & 0.049 & 0.19 & 3.8 & 92 & 99 \\
\hline $\mathrm{NaPA}$ & 0.17 & 85 & 0.05 & 0.20 & 0.042 & 0.15 & 3.6 & 96 & 98 \\
\hline $\mathrm{NaPA}$ & 0.5 & 99 & 0.05 & 0.20 & 0.049 & 0.19 & 3.8 & 97 & 101 \\
\hline$p$-F-PAA & 0.17 & 66 & 0.05 & 0.20 & 0.033 & 0.12 & 3.7 & 95 & 99 \\
\hline$p-\mathrm{CF}_{3}-\mathrm{PAA}$ & 0.17 & 69 & 0.05 & 0.20 & 0.034 & - & - & 90 & 95 \\
\hline$p-\mathrm{CH}_{3}$-PAA & 0.17 & 67 & 0.05 & 0.20 & 0.033 & 0.12 & 3.6 & 92 & 97 \\
\hline$p$-t-Bu-PAA & 0.17 & 68 & 0.05 & 0.20 & 0.033 & 0.13 & 3.7 & 94 & 98 \\
\hline
\end{tabular}

a The starting phenylacetic acid structure where PAA = phenylacetic acid, NaPA = sodium phenylacetate, $p$-F-PAA $=p$-fluorophenylacetic acid, $p$-CF3-PAA $=p$-trifluoromethylphenylacetic acid and $p$-t-Bu-PAA $=p$-t-butylphenylacetric acid.

$\mathrm{b}$ The initial concentration of the phenylacetic acid reactant.

c The initial concentration of the $\mathrm{Cu}(\mathrm{II}) \mathrm{Cl}_{2}$.

$\mathrm{d}$ The number of moles of reactant consumed, determined by gas chromatography (after acidification in the case of sodium phenylacetate).

e The number of moles of $\mathrm{Cu}(\mathrm{II})$ ions consumed, determined by UV/vis spectroscopy.

$\mathrm{f}$ The ratio of the number of moles of $\mathrm{Cu}$ (II) ions consumed to the ration of phenylacetic acid reactant consumed.

$\mathrm{g}$ The chemical yield of the appropriately substituted benzaldehyde formed, measured chromatographically and determined in comparison to the amount of reactant consumed. 
Table 2. Reaction Times, initial concentrations, conversions, and chemical yields for reaction of benzyl alcohols with $\mathrm{Cu}(\mathrm{II}) \mathrm{Cl}_{2}(0.20$ molal $)$ in $\mathrm{H}_{2} \mathrm{O}$ at $250^{\circ} \mathrm{C}$ and 40 bar in fused silica tubes.

\begin{tabular}{|c|c|c|c|c|c|c|c|c|c|}
\hline Reactant ${ }^{a}$ & $\begin{array}{l}\text { Time } \\
\text { (hrs) }\end{array}$ & $\begin{array}{c}\text { Conv. } \\
(\%)\end{array}$ & $\begin{array}{c}\text { Initial } \\
\text { Reactant } \\
(\text { molal) } b\end{array}$ & $\begin{array}{c}\text { Initial } \\
\mathrm{Cu}^{2+} \\
(\text { molal) }\end{array}$ & $\begin{array}{c}\text { Reactant } \\
\text { Consumed } \\
(\text { molal }) \mathrm{d}\end{array}$ & $\begin{array}{c}\mathrm{Cu}^{2+} \\
\text { Consumed } \\
(\mathrm{molal}) \mathrm{e}\end{array}$ & $\begin{array}{c}\text { Consumed } \\
\text { mole ratio }\end{array}$ & $\begin{array}{c}\text { Aldehyde } \\
\% \\
\text { yield } \mathrm{g} \\
\end{array}$ & $\begin{array}{c}\text { Mass } \\
\text { Balance } \\
(\%)\end{array}$ \\
\hline $\mathrm{BZH}$ & 0.5 & 18 & 0.05 & 0.05 & 0.009 & 0.016 & 1.8 & 93 & 98 \\
\hline BZH & 0.5 & 29 & 0.05 & 0.10 & 0.015 & - & - & 94 & 97 \\
\hline $\mathrm{BZH}$ & 0.5 & 43 & 0.05 & 0.20 & 0.021 & 0.051 & 2.4 & 85 & 95 \\
\hline BZH & 1 & 41 & 0.05 & 0.05 & 0.020 & 0.039 & 1.9 & 89 & 92 \\
\hline $\mathrm{BZH}$ & 1 & 65 & 0.05 & 0.10 & 0.032 & 0.079 & 2.4 & 92 & 95 \\
\hline$p-\mathrm{CF}_{3}-\mathrm{BZH}$ & 0.5 & 17 & 0.05 & 0.10 & 0.008 & - & - & 86 & 96 \\
\hline$p-\mathrm{CH}_{3}-\mathrm{BZH}$ & 0.5 & 78 & 0.05 & 0.10 & 0.039 & - & - & 85 & 94 \\
\hline $\begin{array}{c}p-\mathrm{CH}_{3} \mathrm{O}- \\
\mathrm{BZH}\end{array}$ & 0.5 & 99 & 0.05 & 0.10 & 0.049 & - & - & 78 & 91 \\
\hline
\end{tabular}

a The starting benzyl alcohol reactant structure where $\mathrm{BZH}=$ benzyl alcohol, $p-\mathrm{CF}_{3}-\mathrm{BZH}=$ $p$-trifluoromethylbenzyl alcohol, $p-\mathrm{CH}_{3}-\mathrm{BZH}=p$-methylbenzyl alcohol and $p-\mathrm{CH}_{3} \mathrm{O}-\mathrm{BZH}=p$-methoxybenzyl alcohol.

$\mathrm{b}$ The initial concentration of the benzyl alcohol reactant.

c The initial concentration of the $\mathrm{Cu}(\mathrm{II}) \mathrm{Cl}_{2}$.

$\mathrm{d}$ The number of moles of reactant consumed, determined by gas chromatography.

e The number of moles of $\mathrm{Cu}(\mathrm{II})$ ions consumed, determined by UV/vis spectroscopy.

${ }^{f}$ The ratio of the number of moles of $\mathrm{Cu}$ (II) ions consumed to the ration of benzyl alcohol reactant consumed.

$\mathrm{g}$ The chemical yield of the appropriately substituted benzaldehyde formed, measured chromatographically and determined in comparison to the amount of reactant consumed. 
Table 3. Reaction Times, initial concentrations, conversions, and chemical yields for reaction of benzladehydes with $\mathrm{Cu}(\mathrm{II}) \mathrm{Cl}_{2}(0.20$ molal $)$ in $\mathrm{H}_{2} \mathrm{O}$ at $250^{\circ} \mathrm{C}$ and 40 bar in fused silica tubes.

\begin{tabular}{|c|c|c|c|c|c|c|c|c|c|}
\hline Reactant $^{a}$ & $\begin{array}{l}\text { Time } \\
\text { (hrs) }\end{array}$ & $\begin{array}{c}\text { Conv. } \\
(\%)\end{array}$ & $\begin{array}{c}\text { Initial } \\
\text { Reactant } \\
\text { (molal) b }\end{array}$ & $\begin{array}{c}\text { Initial } \\
\text { Cu }^{2+} \\
(\mathbf{m o l a l}) \mathrm{c}\end{array}$ & $\begin{array}{c}\text { reactant } \\
\text { Consumed } \\
(\text { molal })^{d}\end{array}$ & $\begin{array}{c}\mathbf{C u}^{2+} \\
\text { Consumed } \\
(\text { molal }) \mathrm{e}\end{array}$ & $\begin{array}{l}\text { Consumed } \\
\text { mole ratio }\end{array}$ & $\begin{array}{c}\text { Acid } \\
\% \text { yield } g\end{array}$ & $\begin{array}{c}\text { Mass } \\
\text { Balance } \\
(\%)\end{array}$ \\
\hline BZD & 2 & 12 & 0.05 & 0.10 & 0.006 & 0.013 & 2.1 & 90 & 97 \\
\hline BZD & 2 & 15 & 0.05 & 0.10 & 0.007 & 0.017 & 2.3 & 95 & 98 \\
\hline BZD & 2 & 23 & 0.05 & 0.20 & 0.011 & 0.026 & 2.4 & 92 & 98 \\
\hline BZD & 6 & 38 & 0.05 & 0.20 & 0.019 & 0.042 & 2.2 & 97 & 98 \\
\hline BZD & 6 & 39 & 0.05 & 0.20 & 0.019 & - & - & 96 & 99 \\
\hline$p-\mathrm{CF}_{3}-\mathrm{BZD}$ & 6 & 32 & 0.05 & 0.20 & 0.016 & 0.039 & 2.4 & 93 & 96 \\
\hline$p-\mathrm{CF}_{3}-\mathrm{BZD}$ & 6 & 30 & 0.05 & 0.20 & 0.015 & - & - & 97 & 97 \\
\hline$p-\mathrm{CH}_{3}-\mathrm{BZD}$ & 6 & 44 & 0.05 & 0.20 & 0.022 & 0.049 & 2.2 & 95 & 98 \\
\hline$p-\mathrm{CH}_{3}-\mathrm{BZD}$ & 6 & 45 & 0.05 & 0.20 & 0.023 & - & - & 94 & 97 \\
\hline
\end{tabular}

a The starting benzaldehyde reactant structure where $\mathrm{BZD}=$ benzaldehyde, $p-\mathrm{CF}_{3}-\mathrm{BZD}=$ $p$-trifluoromethylbenzaldehyde and $p$ - $\mathrm{CH}_{3}-\mathrm{BZD}=p$-methylbenzaldehyde.

$\mathrm{b}$ The initial concentration of the benzaldehyde reactant.

c The initial concentration of the $\mathrm{Cu}(\mathrm{II}) \mathrm{Cl}_{2}$.

$\mathrm{d}$ The number of moles of reactant consumed, determined by gas chromatography.

e The number of moles of $\mathrm{Cu}(\mathrm{II})$ ions consumed, determined by UV/vis spectroscopy.

${ }^{f}$ The ratio of the number of moles of $\mathrm{Cu}$ (II) ions consumed to the ration of benzaldehyde reactant consumed.

$\mathrm{g}$ The chemical yield of the appropriately substituted benzoic acid formed, measured chromatographically and determined in comparison to the amount of reactant consumed. 